\title{
Effects Of Key Financial Indicators On Earnings Management In Korea's Ready Mixed Concrete Industry
}

Geun Bae Jang, Seoul School of Integrated Sciences \& Technologies University, South Korea

Weon-Jae Kim, Incheon National University, South Korea

\begin{abstract}
Earnings management is the practice of deriving certain benefits by intervening in external financial reporting or misleading certain stakeholders through adjustments to accruals without cash flow involvement or with affecting cash flows through real activities. Using the models of Kothari et al. (2005) and Cohen et al. (2008) for accrualbased earnings management (AEM) and real activities earnings management (REM), respectively, we examined whether relationships exist between key financial indicators, such as cash flows from operations, operating income, and debt dependency level, and AEM and REM in the ready mixed concrete (RMC) industry in Korea. This study is the first to investigate earnings management in Korea's RMC sector. Results showed that operating income and cash flows from operations are significantly negatively related to AEM and REM, consistent with the findings of previous research. By contrast, debt dependency exhibits no significant relationship with AEM and REM, contradicting the findings of most previous studies. As a moderating variable, operating income affects the relationship between cash flows from operations and earnings management with only REM. On these bases, we can infer that earnings management in the Korean RMC industry responds differently to key financial indicators with regards to AEM and REM practice. Overall, companies in the industry implement aggressive earnings management depending on operating income and cash generation ability level rather than debt dependency level. These findings provide important insights for people who are interested in accounting information on the RMC industry in Korea.
\end{abstract}

Keywords: Ready Mixed Concrete Industry; Operating Income; Cash Flow From Operating Activities; Debts Dependency; Earnings Management

\section{INTRODUCTION}

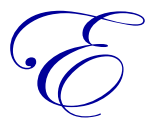

arnings management has been defined differently by researchers. Healey and Warren (1999), for example, stated that it is the exercise of judgment in financial reporting and transaction for the purpose of misleading certain stakeholders regarding the financial performance of a company or achieving target contractual outcomes on the basis of reported financial data. Schipper (1989) defined it as "disclosure management," which is intended to realize private gains by purposefully intervening in external financial reporting.

Two methods of earnings management are used. The first is accrual-based earnings management (AEM), in which accruals in accounting records are adjusted without cash flow involvement, and the second is real earnings management (REM), wherein actual expenses and cash flows are reduced or production costs are managed (Nekhili et al., 2016; Park, 2016, 2012). Cohen et al. (2008) stated that after the Sarbanes-Oxley Law was introduced, companies have been shifting from AEM to REM as a means of managing their earnings. Zang (2012) found that managers switch between the two methods depending on their relative costs, with these executives favoring real activities manipulation and AEM as substitute approaches. Previous studies tended to focus on measuring earnings adjustment in AEM, but recent years have seen increased concentration on REM given the strengthening of accounting regulations.

Various financial indicators, including cash flows from operations, operating income, liability to equity ratio, debt dependency level, free cash flows, leverage, and liquidity ratio, are associated with earnings management (Nekhili et al., 2016; Kim \& Lee, 2015; Kim et al., 2011; Park et al., 2002; Hue, 2009). Companies with low cash flows from 
operations aggressively implement AEM and REM, whereas enterprises with high cash flows from operations practice the opposite (Park et al., 2002); Dechow et al., 1995; DeFond and Subramanyam, 1998). Operating income is negatively related to earnings management (Yoon \& Miller, 2003; Hue 2009).

When a company has a high liability to equity ratio or high debt dependency, it tends to implement upward earnings management (Sercu et al., 2006; Lee, 2005; Fung \& Goodwin, 2013; Choi, 2008). The current research verifies whether the same tendency occurs in the ready mixed concrete (RMC) industry in Korea by using the AEM and REM models proposed by Kothari et al. (2005) and Cohen et al. (2008), respectively. We focus on the relationships between key financial indicators, namely, cash flows from operations, operating income, and debt dependency level, and AEM and REM. We also examine whether operating income, as a moderating variable, affects the relationship between cash flows from operations and earnings management. Most RMC companies in Korea are small and medium-sized enterprises and thus suffer from a limited capacity to access the capital market. These companies depend primarily on loans from private financial institutions, mainly banks. Under this backdrop, RMC companies are driven to implement upward earnings management to reduce borrowing costs and qualify for additional loans from banks. To demonstrate their repayment capability, they are compelled to prove their ability to generate operating cash flows to financial institutions. Similar to other construction industries, the RMC sector is an orderbased industry. For a company to secure orders and become a supplier of construction companies, it needs to implement upward earnings management to ensure that operational performance enables the generation of operating income or cash flows from operations. No evidence has been provided as to whether earnings management in the RMC industry exhibits a pattern similar to that in other industries. Therefore, obtaining empirical evidence on the relationship between key financial indicators and earnings management in this sector offers very important implications.

The rest of the paper is organized as follows. Section 2 is a review of the literature on earnings management and related financial indicators. It also presents the arguments that underlie our hypotheses. Section 3 discusses our research methodology, and Section 4 describes the descriptive statistics of the variables used in this work, the correlations that we derived, and the results of an empirical test. Section 5 concludes the paper.

\section{THEORETICAL BACKGROUND AND HYPOTHESES DEVELOPMENT}

\subsection{Cash Flows from Operations, Operating Income, and Earnings Management}

Previous research generally indicates a negative relationship between operating cash flows and earnings management. As representative studies, Dechow et al. (1995) and DeFond and Subramanyam (1998) confirmed a negative significant relationship between operating cash flows and AEM. Kim and Lee (2015) investigated earnings management in the construction waste disposal industry in Korea, also with a focus on operating cash flows. The authors reported that cash flows from operations are negatively related to earnings management and that low operating cash flows therefore drive increased upward earnings management in AEM and REM. Kim et al. (2011) stated that more discretionary accruals (DAs) are implemented under negative operating cash flows than under positive operating cash flows. Similar findings were presented by Hue (2009) and Yoon and Miller (2002). Hue reported that a company with negative operating cash flows and a positive operating income tends to perform more DAs than a company with negative operating cash flows and a negative operating income. This finding implies that operating income exerts a certain effect on the relationship between cash flows from operations and earnings management. Yoon and Miller explained that when operating performance is poor, firms tend to choose incomeincreasing strategies. That is, the lower a company's operating income, the stronger the tendency toward upward earnings management. On the basis of these studies, we formulate the following hypotheses for RMC companies in Korea:

Hypothesis 1: Earnings management via AEM and REM will decrease with level of operating income.

Hypothesis 2: Earnings management via AEM and REM will decrease with level of cash flows from operations.

Hypothesis 3: Operating income level will affect the relationship between cash flows from operations and earnings management via AEM and REM. 


\subsection{Debt Dependency and Earnings Management}

Most previous studies showed a statistically positive relationship between leverage (debt dependency level: total debts divided by sum of total liabilities and total shareholders' equities) and earnings management, indicating that high-leverage companies favor upward earnings management. Fung and Goodwin (2013) found that short-term debt is positively associated with AEM (measured by DAs). Park and Cho (2013) examined the effects of additional borrowing and debt ratio on earnings management for non-listed SMEs. The authors found that the larger the scale of additional debt and the higher the total debt ratio, the stronger the tendency of companies to opt for upward earnings management. In classifying a corporation's liabilities into trade-related liabilities and debts from banks, Sercu et al. (2006) found that earnings management is more significantly related to bank debts than trade-related liabilities. In the Australian context, Jones (2001) demonstrated that old-economy firms engage in significant earnings management, which is positively associated with leverage. Kim and Lee (2015) showed that the Korean construction waste disposal industry is characterized by a positive relationship between debt dependency level and earnings management. Kim and Bae (2008) pointed out that unlisted SMEs are more likely to rely on loans from financial institutions, such as banks, for their financing needs and are more likely to implement upward earnings managements to avoid reporting losses from the loans that they derive from financial institutions. We expect the same relationship to occur in Korea's RMC industry and accordingly formulate the following hypothesis:

Hypothesis 4: Earnings management via AEM and REM will increase with level of debt dependency.

\section{RESEARCH METHODOLOGY}

\subsection{Sample Selection}

The sample consisted of Korean RMC companies that disclose their financial conditions in the DART system of the Korean Financial Supervisory Service's website. We excluded firms that engage in businesses other than RMC for data purity and those whose annual financial data span a period of less than eight years. The data obtained from the sample comprised eight-year annual data covering 2008 to 2015. The final dataset consisted of 176 firm-year observations.

\subsection{Definition and Measurement of Variables}

\subsubsection{Measuring Accrual-Based Earnings Management}

We used DAs as a proxy for AEM. DAs represent unexplained accruals, which are calculated by subtracting estimated normal accruals from total accruals. Kothari et al. (2005) developed a performance-matched DA measure by using the revised Jones (1991) model to control performance effects in the estimation of DAs. The authors used ROA as a variable of performance to control the overestimation of DAs. In the present research, the coefficients of total accruals were calculated by using equation (1) in regression. We then estimated DAs by subtracting normal accruals from total accruals by using equation (2). We also used DAs as a measure of AEM by using Kothari et al.'s model as follows:

$$
\begin{aligned}
& \frac{T A_{t}}{A_{t-1}}=\alpha_{0}+\beta_{1} \frac{1}{A_{t-1}}+\beta_{2} \frac{\Delta S_{t}-\Delta A R_{t}}{A_{t-1}}+\beta_{3} \frac{P P E_{t}}{A_{t-1}}+\beta_{4} R O A_{t}+\varepsilon_{t} \\
& D A_{t}=\frac{T A_{t}}{A_{t-1}}-\left(\alpha_{0}+\beta_{1} \frac{1}{A_{t-1}}+\beta_{2} \frac{\Delta S_{t}-\Delta A R_{t}}{A_{t-1}}+\beta_{3} \frac{P P E_{t}}{A_{t-1}}+\beta_{4} R O A_{t}\right)
\end{aligned}
$$

$T A_{t}: \quad$ Year ${ }_{\mathrm{t}}$ Total Accrual (Net Income - CFO)

$D A_{t}: \quad$ Year $_{\mathrm{t}}$ Discretionary Accruals

$A_{t-1}: \quad$ Year $_{\mathrm{t}-1}$ Total Assets

$\Delta S_{t}: \quad$ Year $_{\mathrm{t}}$ Sales Change

$\Delta A R_{t}: \quad$ Year $_{\mathrm{t}} \mathrm{AR}$ Change 
$P P E_{t}: \quad$ Year ${ }_{t}$ Plant, Properties and Equipment - net

$R O A_{t}: \quad$ Year ${ }_{t}$ Return on Total Assets (Net Income / Year ${ }_{\mathrm{t}-1}$ Total Assets)

$\varepsilon_{t}: \quad \quad$ Year ${ }_{\mathrm{t}}$ Residual

\subsubsection{Measuring Real Activities-Based Earnings Management}

We used the REM model proposed by Cohen et al. (2008), who developed an integrated real earnings management measure that is similar to equation (3) by combining abnormal cash flows (ACFO), abnormal production costs (APC) and abnormal selling, and general and administrative expenses (ASGA). The authors combined these elements to verify the level of real earnings management implemented by corporations. The signs of ACFO and ASGA are opposite to that of APC. Real earnings management occurs when ACFO and ASGA decrease and when APC increases.

$$
R E M=\frac{1}{3} X\{(-) A C F O+(+) A P C+(-) A S G A\}
$$

Roychowdhury (2006) developed a representative real earnings management model that considers ACFO, APC, and ASGA as measures of real activities that are subjected to earnings management.

ACFO from operating activities are price discounts and credit sales by enabling the relaxation of credit control. ACFO is used to measure abnormal cash flows by comparing increases in sales and increases in cash flows. Roychowdhury developed equations (4) and (5) on the basis of Dechow et al.'s (1998) model, in which normal cash flows from operations are assumed to have a linear relationship with sales changes. He estimated the coefficients of equation (4) and calculated ACFO by subtracting normal cash flows from operations from total cash flows from operations, as in equation (5). The calculation is presented below:

$$
\begin{aligned}
& \frac{C F O_{t}}{A_{t-1}}=\alpha_{0}+\beta_{1} \frac{1}{A_{t-1}}+\beta_{2} \frac{S_{t}}{A_{t-1}}+\beta_{3} \frac{\Delta S_{t}}{A_{t-1}}+\varepsilon_{t} \\
& \frac{A C F O_{t}}{A_{t-1}}=\frac{C F O_{t}}{A_{t-1}}-\left(\alpha_{0}+\beta_{1} \frac{1}{A_{t-1}}+\beta_{2} \frac{S_{t}}{A_{t-1}}+\beta_{3} \frac{\Delta S_{t}}{A_{t-1}}\right)
\end{aligned}
$$

$\mathrm{CFO}_{t}: \quad$ Year $_{\mathrm{t}}$ Actual Cash Flow from Operations

$A C F O_{t}$ : Year ${ }_{\mathrm{t}}$ Abnormal Cash Flow from Operations

$S_{t}: \quad$ Year $_{\mathrm{t}}$ Sales

$\Delta S_{t}: \quad$ Year ${ }_{t}$ Sales Change

$A_{t-1}: \quad$ Year $_{\mathrm{t}-1}$ Total Assets

$\varepsilon_{t}: \quad$ Year ${ }_{\mathrm{t}}$ Residual

APC is used to examine whether a corporation increases or decreases production quantities to perform earnings management that is based on the adjustment of the costs of goods sold. Roychowdhury (2006) used equation (6) to estimate coefficients and total production costs based on normal sales changes and production cost relationships. He then calculated APC by using equation (7) to subtract normal production costs from total production costs.

$$
\begin{aligned}
& \frac{P C_{t}}{A_{t-1}}=\alpha_{0}+\beta_{1} \frac{1}{A_{t-1}}+\beta_{2} \frac{S_{t}}{A_{t-1}}+\beta_{3} \frac{\Delta S_{t}}{A_{t-1}}+\beta_{4} \frac{\Delta S_{t-1}}{A_{t-1}}+\varepsilon_{t} \\
& \frac{A P C_{t}}{A_{t-1}}=\frac{P C_{t}}{A_{t-1}}-\left(\alpha_{0}+\beta_{1} \frac{1}{A_{t-1}}+\beta_{2} \frac{S_{t}}{A_{t-1}}+\beta_{3} \frac{\Delta S_{t}}{A_{t-1}}+\beta_{4} \frac{\Delta S_{t-1}}{A_{t-1}}\right)
\end{aligned}
$$




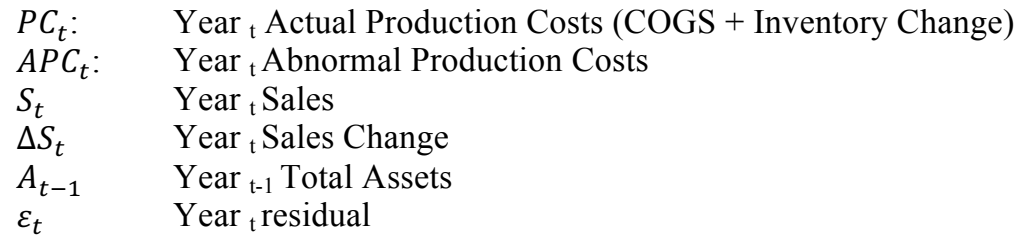

Abnormal selling and ASGAs are used to measure the effects of real earnings management on the selling and ASGAs of management. Generally, management tends to increase or decrease these expenses and thus enables earnings management because the expenses are discretionary in nature. Roychowdhury estimated normal discretionary expenses by using equation (8), which is based on a linear relationship with sales. He then calculated ASGA by subtracting normal SGA from total SGA through equation (9).

$$
\begin{aligned}
& \frac{S G A_{t}}{A_{t-1}}=\alpha_{0}+\beta_{1} \frac{1}{A_{t-1}}+\beta_{2} \frac{S_{t}}{A_{t-1}}+\beta_{3} \frac{S_{t-1}}{A_{t-1}}+\varepsilon_{t} \\
& \frac{A S G A_{t}}{A_{t-1}}=\frac{S G A_{t}}{A_{t-1}}-\left(\alpha_{0}+\beta_{1} \frac{1}{A_{t-1}}+\beta_{2} \frac{S_{t}}{A_{t-1}}+\beta_{3} \frac{S_{t}}{A_{t-1}}+\right)
\end{aligned}
$$

$S G A_{t}: \quad$ Year $_{\mathrm{t}}$ Actual Discretionary Expenses (SGA)

$A S G A_{t}: \quad$ Year $_{\mathrm{t}}$ Abnormal Discretionary Expenses

$S_{t}: \quad$ Year $_{\mathrm{t}}$ Sales

$A_{t-1}$ : $\quad$ Year $_{\mathrm{t}-1}$ Total Assets

$\varepsilon_{t}: \quad$ Year ${ }_{\mathrm{t}}$ residual

\subsubsection{Control Variables}

We used various control variables presented in previous research to reduce statistical error and increase the accuracy with which statistical inferences are made (Becker et al., 1998; Ashbaugh et al., 2003; DeFond \& Jiambalvo, 1994; Kasznik ,1999; Kothari et al., 2005, etc.). The specific control variables used in the present study were corporation size (SIZE), liabilities and equity ratio (LEV), return on total assets (ROA), growth of total assets (GRW), prior year's total accruals (TA), net losses (LOSS), and year (YEAR). SIZE is a log value of the amount of beginning total assets, LEV is derived by dividing total liability by shareholder equity, ROA is obtained by dividing net income by beginning total assets, GRW is obtained by dividing ending total assets by beginning total assets, and TA is the prior year's net income minus the prior year's operating cash flows. For LOSS, we used a dummy variable that was assigned a value of 1 for net loss and 0 for net income.

\subsection{Research Model}

As previously stated, this study examined the relationships between certain key financial indicators and earnings management in the RMC industry in Korea. We used equations (10) to (13) for validation. In these equations, we used the DA in equation (2) and the REM in equation (3) as proxies for AEM and REM, respectively. The major independent variables used were operating cash flows (CFO), operating income (OI), and debt dependency (DEBT). OI was used as a moderating variable in examining the relationship between CFO and earnings. CFO was measured by dividing CFO by beginning total assets for standardization. OI was measured by dividing it by sales. A high OI is preferable because it generally brings more cash to companies. DEBT is the financial ratio of total debts against the sum of total liabilities and shareholders' equities. This ratio is used as an indicator of a company's financial health and profitability. A low DEBT is regarded as favorable from the perspective of financial capital structure.

$$
\begin{aligned}
& D A_{i t}\left(\text { or } R E M_{i t}\right)=\alpha_{0}+\beta_{1} C F O_{i t}+\beta_{2} S I Z E_{i t}+\beta_{3} L E V_{i t}+\beta_{4} R O A_{i t}+\beta_{5} G R W_{i t}+\beta_{6} T A_{i t} \\
& +\beta_{7} L O S S_{i t}+\sum Y E A R+\varepsilon_{i t D}
\end{aligned}
$$




$$
\begin{aligned}
& D A_{i t}\left(\text { or } R E M_{i t}\right)=\alpha_{0}+\beta_{1} O I_{i t}+\beta_{2} S I Z E_{i t}+\beta_{3} L E V_{i t}+\beta_{4} R O A_{i t}+\beta_{5} G R W_{i t}+\beta_{6} T A_{i t} \\
& +\beta_{7} L_{O S S_{i t}}+\sum Y E A R+\varepsilon_{i t} \\
& D A_{i t}\left(\text { or } R E M_{i t}\right)=\alpha_{0}+\beta_{1} C F O_{i t}+\beta_{2} O I_{i t}+\beta_{3} C F O X O I_{i t}+\beta_{4} S_{Z} Z E_{i t}+\beta_{5} L E V_{i t}+\beta_{6} R O A_{i t} \\
& +\beta_{7} G R W_{i t}+\beta_{8} T A_{i t}+\beta_{9} L O S S_{i t}+\sum Y E A R+\epsilon_{i t} \\
& D A_{i t}\left(\text { or } R E M_{i t}\right)=\alpha_{0}+\beta_{1} D E B T_{i t}+\beta_{2} S I Z E_{i t}+\beta_{3} L E V_{i t}+\beta_{4} R O A_{i t}+\beta_{5} G R W_{i t}+\beta_{6} T A_{i t} \\
& +\beta_{7} L_{O S S}+\sum Y E A R+\varepsilon_{i t}
\end{aligned}
$$

\section{Dependent Variables}

$D A_{i t}: \quad$ Discretionary accruals based on Kothari et al. (2005) model

$R E M_{i t}$ : Integrated real earnings measurement based on Cohen et al. (2008) and Roychowdhury (2006)

\section{Independent Variables}

$C F O_{i t}: \quad$ Cash flow from operations (continuous variable)

$O I_{i t}: \quad$ Operating income (continuous variable)

$D E B T_{i t}$ : Debts dependency (continuous variable)

\section{Moderating Variable}

$O I_{i t}$ : Dummy variable (for company $\mathrm{i}$ and year $\mathrm{t}$, if $\mathrm{OI}$ is bigger than average is 1 , if not 0

\section{Control Variables}

$S I Z E_{i t}: \quad$ Company size

$L E V_{i t}: \quad$ Liabilities to equity Ratio

$R O A_{i t}: \quad$ Total assets return

$G R W_{i t}$ : Total assets growth rate

$T A_{i t}: \quad$ Prior year total accruals

LOSS $_{i t}$ : Net losses

Year: $\quad$ Year dummy

\section{RESULTS OF EMPIRICAL STUDY}

\subsection{Descriptive Statistics and Correlations}

Table 1 presents the descriptive statistics of the major variables used in this study. The mean of the proxies for the dependent variables (DA, REM, ACFO, APC, and ASGA) is 0 because these values were estimated by subtracting expected values, which were derived from the regression analysis, from actual values. The same mean was reported in previous studies. The mean of DA and REM as earnings management proxies is .001 , with median values of .0133 and .0114 , respectively. The positive median indicates that the sample companies implemented earnings management via AEM and REM during the analysis period. The minimum and maximum of DA and REM distributions are -.49 to .25 and -.20 to .11 , respectively, indicating that the DA spread is larger than the REM spread. The mean and median of OI as an independent variable are .0478 and .0514 , which indicates that the average OI percentage for the observations is $4.78 \%$. The mean and median of DEBT (total debts/total liabilities and total equities) are .1925 and .1574 , respectively, and those of CFO are .0780 and .0589 , respectively.

As indicated earlier, the control variables were SIZE, LEV, ROA, GRW, TA, LOSS, and YEAR. SIZE was calculated using the natural log value of total assets, and its mean and median are 10.3886 and 10.3240 , respectively. Their spread is minimal. The mean and median of LEV are 1.7218 and 1.2132, respectively, indicating that the average LEV of the companies reflects $172 \%$ of liabilities against total equities. The means of ROA and GRW are .0380 and .075 , respectively, indicating that the average ROA is $3.8 \%$ and that the average total asset growth rate is $7.51 \%$. The mean of TA is -.0385 . The mean of LOSS is .1534; that is, $15.34 \%$ of the observations reflected net losses for the companies. 
Table 1. Descriptive Statistics for Major Variables

\begin{tabular}{|c|c|c|c|c|c|c|}
\hline Variables & Names & Mean & SD & Median & Minimum & Maximum \\
\hline \multirow{5}{*}{$\begin{array}{l}\text { Dependent } \\
\text { Variables }\end{array}$} & DA & .0001 & .1019 & .0133 & -.49 & .25 \\
\hline & REM & .0001 & .0584 & .0114 & -.20 & .11 \\
\hline & $\mathrm{ACFO}$ & .0001 & .1019 & -.0053 & -.25 & .55 \\
\hline & APC & .0001 & .0748 & .0748 & -.21 & .16 \\
\hline & ASGA & .0001 & .0699 & -.0208 & -.11 & .27 \\
\hline \multirow{3}{*}{$\begin{array}{l}\text { Independent } \\
\text { Variables }\end{array}$} & OI & .0478 & .3928 & .0514 & -.12 & .15 \\
\hline & DEBT & .1925 & .1075 & .1574 & .00 & .62 \\
\hline & $\mathrm{CFO}$ & .0780 & .1075 & .0589 & -.15 & .63 \\
\hline \multirow{6}{*}{$\begin{array}{l}\text { Control } \\
\text { Variables }\end{array}$} & SIZE & 10.3886 & .2973 & 10.324 & 9.86 & 11.45 \\
\hline & LEV & 1.7218 & 1.4568 & 1.2132 & .15 & 7.63 \\
\hline & ROA & .0380 & .0675 & .0357 & -.33 & .22 \\
\hline & GRW & .0751 & .1785 & .0512 & -.27 & 1.04 \\
\hline & TA & -.0385 & .1089 & -.0243 & -.59 & .25 \\
\hline & LOSS & .1534 & .3614 & .000 & .000 & 1.000 \\
\hline
\end{tabular}

Definition for variables

DA : Discretionary accruals, REM : Real earnings management, ACFO : Abnormal cash flows from operations, APC : Abnormal production costs, ASGA : Abnormal selling, general and administrative expenses, OI : operating income (operating income/Sales), CFO : Cash flows from operations (CFO/Beginning total assets), SIZE : Company size(Natural log value of beginning total assets), LEV : Liabilities to equity(Total liabilities/Net assets), ROA : Return of total assets(Net income/Beginning total assets), GRW : Total assets growth\{(Ending total assetsBeginning total assets)/Beginning total assets $\}$, TA : Prior year total accruals $\{$ (Prior year net income-Prior year cash flows from operations $) /$ Prior year beginning total assets $\}$, LOSS : Net losses(Dummy variable, Net losses $=1$, Otherwise $=0$ ).

Table 2 presents Pearson's correlation analysis result among variables used in the study.

Table 2 presents the results of the Pearson's correlation analysis of the variables. The DA and REM of the dependent variables show a statistically and highly positive significance of .550 at the $1 \%$ level, demonstrating that the DA and REM move in the same direction. OI shows a significant negative correlation (-.259) with REM at $1 \%$ but a non-significant negative correlation (-.135) with DA. This result suggests that companies with low operating incomes tend to more aggressively implement real earnings management than do enterprises with high operating incomes. This implication, however, does not apply to DA. DEBT does not show a statistically significant relationship with DA or REM, and CFO shows a significant negative correlation with both DA (-.896) and REM ($.615)$ at the $1 \%$ level. Companies with low cash generation more aggressively implement earnings management through both accruals and real earnings activities.

The correlation between OI and CFO is significant (.300) at the $1 \%$ level. OI moves in the same direction as CFO. DEBT exhibits a statistically non-significant relationship with CFO but a statistically significant relationship with operating income at the $5 \%$ level. We also tested multicollinearity on the basis of tolerance and VIF and found that the values fall within the acceptable range.

Table 2. Pearson Correlations among Variables

\begin{tabular}{|c|c|c|c|c|c|c|c|c|c|c|c|}
\hline & $\overline{\text { DA }}$ & REM & OI & DEBT & CFO & SIZE & LEV & ROA & GRW & TA & LOSS \\
\hline DA & 1.000 & & & & & & & & & & \\
\hline REM & $.550^{* *}$ & 1.000 & & & & & & & & & \\
\hline OI & -.135 & $-.259^{* *}$ & 1.000 & & & & & & & & \\
\hline DEBT & .039 & .038 & $-.167^{*}$ & 1.000 & & & & & & & \\
\hline CFO & $-.896^{* *}$ & $-.615^{* *}$ & $.300^{* *}$ & -.121 & 1.000 & & & & & & \\
\hline SIZE & .001 & .045 & -.015 & -.094 & -.121 & 1.000 & & & & & \\
\hline LEV & -.006 & .075 & $.217^{* *}$ & $.750^{* *}$ & -.053 & -.120 & 1.000 & & & & \\
\hline ROA & .083 & -.135 & $.584^{* *}$ & $-.405^{* *}$ & $.246^{* *}$ & -.115 & $-.411^{* *}$ & 1.000 & & & \\
\hline GRW & .011 & -.095 & .058 & .050 & $.155^{*}$ & $-.220^{* *}$ & .028 & $.234^{* *}$ & 1.000 & & \\
\hline TA & .071 & .013 & .027 & $.186^{*}$ & -.047 & .055 & -.146 & .040 & .076 & 1.000 & \\
\hline LOSS & -.074 & .129 & $-.542^{* *}$ & .119 & -.129 & .077 & $.228^{* *}$ & $-.628^{* *}$ & -.142 & -.117 & 1.000 \\
\hline
\end{tabular}

Variable definition is same with that of bottom of Table 1 


\subsection{Regression Analyses Results}

\subsubsection{Test Results on Effects of Cash Flows from Operations on Earnings Management}

Table 3 presents the results of the hierarchical regression analysis for Hypothesis 1, which revolves around the effects of CFO on earnings management in the Korean RMC companies during the analysis period. In step one, we used various control variables. Table 3 shows only the results of step 2 given space limitations. CFO's effects on DA and REM are statistically significant at the $0.1 \%$ level. The $\mathrm{R}^{2}$ values of DA and REM are .917 and .388 , respectively. These values explain $92 \%$ of the DA and $39 \%$ of the REM. The tolerance of the variables and the VIF are close to 1 , indicating the near-absence of multicollinearity.

The coefficient of CFO as an independent variable for DA and REM are -.939 and -.340, respectively, and both negative values are statistically significant at the $0.1 \%$ level. This finding implies that companies with low cash generation tend to more aggressively implement AEM and REM than do companies with high cash generation. Most of the effects of the control variables, except TA and LOSS, on DA are statistically significant at the $0.1 \%$ to $1 \%$ level. However, their effects on REM are statistically non-significant, indicating that CFO is the key explanatory factor in REM.

Table 3. Regression Results on Effects of Operating Cash Flows on Earnings Management

\begin{tabular}{|c|c|c|c|c|c|c|}
\hline \multirow{2}{*}{ Input Variables } & \multicolumn{2}{|c|}{ DA } & \multicolumn{2}{|c|}{ REM } & \multirow{2}{*}{ Tolerance } & \multirow{2}{*}{ VIF } \\
\hline & B & $\mathbf{t}$ & B & $\mathbf{t}$ & & \\
\hline Constant & .247 & $2.947^{* *}$ & .063 & .480 & & \\
\hline SIZE & -.003 & $-2.474^{*}$ & -.004 & -.358 & .916 & 1.092 \\
\hline LEV & .005 & $2.862^{* *}$ & .002 & .907 & .773 & 1.293 \\
\hline ROA & .512 & $10.512^{* * *}$ & .096 & 1.268 & .476 & 2.103 \\
\hline GRW & .040 & $2.963^{* *}$ & -.005 & -.261 & .881 & 1.135 \\
\hline TA & .019 & .885 & .002 & .051 & .949 & 1.054 \\
\hline LOSS & .003 & .390 & .017 & 1.325 & .594 & 1.683 \\
\hline Year Dummy & \multicolumn{2}{|c|}{ Included } & \multicolumn{2}{|c|}{ Included } & & \\
\hline $\mathrm{CFO}$ & -.939 & $-42.710^{* * *}$ & -.340 & $-9.936^{* * *}$ & .920 & 1.087 \\
\hline$R^{2}\left(\triangle R^{2}\right)$ & \multicolumn{2}{|c|}{$.917(.903)$} & \multicolumn{2}{|c|}{$.388(.360)$} & & \\
\hline $\mathrm{F}$ & \multicolumn{2}{|c|}{$264.616^{* * *}$} & \multicolumn{2}{|c|}{$15.227^{* * *}$} & & \\
\hline
\end{tabular}

Variable definition is same with that of bottom of Table 1

\subsubsection{Test Results on Effects of Operating Income on Earnings Management}

Table 4 presents the hierarchical regression analysis results for Hypothesis 2, which revolves around the effects of OI on earnings management in the RMC companies. As with the analysis for Hypothesis 1, step 1 involved the use of various control variables, but Table 4 shows only the results of step 2 because of space limitations. With respect to DAs, excluding the effects of the control variables, OI's contribution to the overall explanation for DAs is statistically significant at $1 \%$. The tolerance level of the variables is closer to 1 than 0 , and their VIF level is nearer to 1 than 10 . These values demonstrate the near-absence of multicollinearity.

The coefficient of OI is -.825 and is statistically significant at the $1 \%$ level, showing that companies with high operating incomes practice earnings management to a lesser extent through DA. The coefficient of ROA is .349 and is significant at the $5 \%$ level. The OI coefficient of REM is -.432 . This value is significant at the $1 \%$ level, indicating that low operating incomes tend to drive more aggressive real earnings management. No other variable exhibits statistical significance at the 5\% level. 
Table 4. Regression Results on Effects of OI on Earnings Management

\begin{tabular}{|c|c|c|c|c|c|c|}
\hline \multirow{2}{*}{ Input Variables } & \multicolumn{2}{|c|}{ DA } & \multicolumn{2}{|c|}{ REM } & \multirow{2}{*}{ Tolerance } & \multirow{2}{*}{ VIF } \\
\hline & B & $\mathbf{t}$ & B & $\mathbf{t}$ & & \\
\hline Constant & -.065 & -.233 & -.053 & -.333 & & \\
\hline SIZE & .009 & .337 & .007 & .444 & .917 & 1.090 \\
\hline LEV & .004 & .721 & .002 & .691 & .772 & 1.295 \\
\hline ROA & .349 & $2.030^{*}$ & .071 & .725 & .424 & 2.359 \\
\hline GRW & -.024 & -.530 & -.031 & -1.195 & .880 & 1.136 \\
\hline TA & .063 & .886 & .017 & .415 & .952 & 1.051 \\
\hline LOSS & -.032 & -1.148 & .000 & -.019 & .549 & 1.822 \\
\hline Year Dummy & \multicolumn{2}{|c|}{ Included } & \multicolumn{2}{|c|}{ Included } & & \\
\hline OI & -.825 & $-3.315^{* *}$ & -.432 & $-3.035 * *$ & .599 & 1.669 \\
\hline $\mathrm{R} 2(\triangle \mathrm{R} 2)$ & \multicolumn{2}{|c|}{$.074(.061)$} & \multicolumn{2}{|c|}{$.079(.050)$} & & \\
\hline $\mathrm{F}$ & \multicolumn{2}{|c|}{1.931} & \multicolumn{2}{|c|}{$2.063^{*}$} & & \\
\hline
\end{tabular}

Variable definition is same with that of bottom of Table 1

4.2.3 Test Results on Moderating Effects of Operating Income on the Relationship between Operating Cash Flows and Earnings Management

Table 5 presents the effects of CFO on earnings management, which vary depending on OI level (low and high). The effects are divided into two groups on the basis of the average OI. We used hierarchical regression analysis, and in step 1, employed various control variables. Table 5 presents only the step 2 results because of space limitations. The coefficients of CFO on DA are -.927 for the low operating income group and -.942 for the high operating income group. Given that these negative values are statistically significant at the $0.1 \%$ level, companies with low cash generation more aggressively implement AEM than do companies with high cash generation, regardless of OI level. The coefficients of CFO on REM are -.290 and -.358 for the low and high operating income groups, respectively. These negative values are also statistically significant at the $0.1 \%$ level, identical to the results for the DA case. 
Table 5. Effects of OI level on the relations between CFO and Earnings Management Depending

\begin{tabular}{|c|c|c|c|c|c|}
\hline \multirow{3}{*}{$\begin{array}{c}\text { Dependent } \\
\text { Variables }\end{array}$} & \multirow{3}{*}{ Input Variables } & \multicolumn{4}{|c|}{ Operating Income } \\
\hline & & \multicolumn{2}{|c|}{ Below Mean(OI=0) } & \multicolumn{2}{|c|}{ Above $\operatorname{Mean}(\mathrm{OI}=1)$} \\
\hline & & B & $\mathbf{T}$ & B & $\mathbf{t}$ \\
\hline \multirow{11}{*}{ DA } & Constant & .340 & $4.054^{* * *}$ & .014 & .082 \\
\hline & SIZE & -.027 & $-3.457^{* * *}$ & .001 & .050 \\
\hline & LEV & .001 & .730 & .012 & $2.969^{* *}$ \\
\hline & ROA & .355 & $5.582^{* * *}$ & .669 & $7.50^{* * *}$ \\
\hline & GRW & .041 & $2.964^{* *}$ & .013 & .461 \\
\hline & $\mathrm{TA}$ & .043 & 1.417 & .008 & .243 \\
\hline & LOSS & -.002 & -.300 & -.011 & -.435 \\
\hline & Year Dummy & \multicolumn{2}{|c|}{ Included } & \multicolumn{2}{|c|}{ Included } \\
\hline & $\mathrm{CFO}$ & -.927 & $-29.772^{* * *}$ & -.943 & $-26.656^{* * *}$ \\
\hline & $\mathrm{R} 2(\triangle \mathrm{R} 2)$ & \multicolumn{2}{|c|}{$.912(.841)$} & \multicolumn{2}{|c|}{$.931(.728)$} \\
\hline & $\mathrm{F}$ & \multicolumn{2}{|c|}{$137.332^{* * *}$} & \multicolumn{2}{|c|}{$129.898^{* * *}$} \\
\hline \multirow{11}{*}{ REM } & Constant & .072 & .431 & .088 & .406 \\
\hline & SIZE & -.005 & -.292 & -.009 & -.427 \\
\hline & LEV & .001 & .226 & .007 & 1.404 \\
\hline & ROA & .114 & .902 & .189 & 1.701 \\
\hline & GRW & -.013 & -.473 & -.015 & -.405 \\
\hline & TA & -.006 & -.099 & -.008 & -.193 \\
\hline & LOSS & .016 & 1.004 & .020 & .611 \\
\hline & Year Dummy & \multicolumn{2}{|c|}{ Included } & \multicolumn{2}{|c|}{ Included } \\
\hline & $\mathrm{CFO}$ & -.290 & $-4.688^{* * *}$ & -.358 & $-8.107^{* * *}$ \\
\hline & $\mathrm{R} 2(\triangle \mathrm{R} 2)$ & \multicolumn{2}{|c|}{$.229(.182)$} & \multicolumn{2}{|c|}{$.521(.470)$} \\
\hline & $\mathrm{F}$ & \multicolumn{2}{|c|}{$3.946^{* * *}$} & \multicolumn{2}{|c|}{$10.406^{* * *}$} \\
\hline
\end{tabular}

Operating income $(\mathrm{OM})$ is a dummy variable (0: Below average, 1: Above average) and definition for other variables are same with that of bottom of Table 1

By hierarchical regression analysis, we verified Hypothesis 3, which centers on the moderating effects of OI on the relationship between CFO and earnings management. The results are summarized in Table 6. In step 1, we used various control variables, but Table 6 shows only the results of steps 2 to 4 given space limitations. With regard to the DA in model $1, \mathrm{R}^{2}$ is $93.1 \%$ when CFO is used as the independent variable. This value increases to $93.3 \%$ to 93.6\% when additional moderating variables, that is, OI and the combined effects of OI and CFO, are used. However, the combined effects are statistically non-significant for DA. In the case of the REM in model $1, \mathrm{R}^{2}$ is $52.1 \%$ when CFO is employed as the independent variable, after which this value increases to $54.4 \%$ to $58.2 \%$ when additional moderating variables, that is, OI and the combined effects of OI and CFO, are used. In contrast to the DA case, the REM case exhibits a combined effect that is statistically significant at the $5 \%$ level. This finding indicates that OI exerts a moderating effect on cash flows for real earnings management. 
Table 6. Moderating Effects of OI on the relation between CFO and Earnings Management

\begin{tabular}{|c|c|c|c|c|c|c|c|}
\hline \multirow{2}{*}{$\begin{array}{c}\text { Dependent } \\
\text { Variables }\end{array}$} & \multirow[b]{2}{*}{ Input Variables } & \multicolumn{2}{|c|}{ Model 1} & \multicolumn{2}{|c|}{ Model 2} & \multicolumn{2}{|c|}{ Model 3} \\
\hline & & B & $\mathbf{t}$ & B & $\mathbf{t}$ & B & $\mathbf{t}$ \\
\hline \multirow{12}{*}{ DA } & Constant & .014 & .082 & .070 & .391 & .009 & -.051 \\
\hline & SIZE & .001 & .050 & -.003 & -.156 & .003 & .160 \\
\hline & LEV & .012 & $2.969^{* *}$ & .011 & $2.812^{* *}$ & .012 & $3.002^{* *}$ \\
\hline & ROA & .669 & $7.500^{* * *}$ & .715 & $7.461^{* * *}$ & .750 & $7.745^{* * *}$ \\
\hline & GRW & .013 & .461 & .010 & .355 & -.002 & -.084 \\
\hline & TA & .008 & .243 & .010 & .312 & .009 & .290 \\
\hline & LOSS & -.011 & $-.435^{* *}$ & .000 & .002 & .004 & .150 \\
\hline & $\mathrm{CFO}$ & -.943 & $-26.656^{* * *}$ & $-26.784^{* * *}$ & 1.272 & -.706 & -4.761 \\
\hline & OI & & & -1.269 & 1.266 & .022 & .082 \\
\hline & CFO X OI & & & & .794 & 3.247 & -1.674 \\
\hline & $\mathrm{R}^{2}\left(\triangle \mathrm{R}^{2}\right)$ & \multicolumn{2}{|c|}{$.931(.728)$} & \multicolumn{2}{|c|}{$.933(.002)$} & \multicolumn{2}{|c|}{$.936(.003)$} \\
\hline & $\mathrm{F}$ & \multicolumn{2}{|c|}{$129.898^{* * *}$} & \multicolumn{2}{|c|}{$114.898^{* * *}$} & \multicolumn{2}{|c|}{$105.234^{* * *}$} \\
\hline \multirow{12}{*}{ REM } & Constant & .088 & .406 & .186 & .845 & .325 & 1.480 \\
\hline & SIZE & -.009 & -.427 & -.015 & -.722 & -.024 & -1.195 \\
\hline & LEV & .007 & 1.404 & .006 & 1.204 & .005 & 1.022 \\
\hline & ROA & .189 & 1.701 & .270 & $2.283^{*}$ & .208 & 1.782 \\
\hline & GRW & -.015 & -.405 & -.020 & -.563 & .002 & .066 \\
\hline & TA & -.008 & -.193 & -.004 & -.098 & -.002 & -.062 \\
\hline & LOSS & .020 & .611 & .040 & 1.181 & .033 & .259 \\
\hline & $\mathrm{CFO}$ & -.358 & $-8.107^{* * *}$ & -.365 & $-8.373^{* * *}$ & -.789 & $-4.420^{* * *}$ \\
\hline & OI & & & -.479 & -1.815 & -.997 & $-3.011^{* *}$ \\
\hline & CFO X OI & & & & & 5.710 & $2.445^{*}$ \\
\hline & $\mathrm{R}^{2}\left(\triangle \mathrm{R}^{2}\right)$ & \multicolumn{2}{|c|}{$.521(.470)$} & \multicolumn{2}{|c|}{$.544(.023)$} & \multicolumn{2}{|c|}{$.582(.038)$} \\
\hline & $\mathrm{F}$ & \multicolumn{2}{|c|}{$10.406^{* * *}$} & \multicolumn{2}{|c|}{$9.829^{* * *}$} & \multicolumn{2}{|c|}{$10.060^{* * *}$} \\
\hline
\end{tabular}

$* \mathrm{p}<.05, * * \mathrm{p}<.01, * * * \mathrm{p}<.001$

Variable definition is same with that of bottom of Table 1

\subsubsection{Test Results on Effects of Debt Dependency on Earnings Management}

Table 7 presents the results of hierarchical regression analysis for Hypothesis 4, which pertains to the effects of DEBT on earnings management in the RMC companies. Again, step 1 involved various control variables, and only the results of step 2 are presented in the table because of space limitations. The tolerance levels of all the variables are closer to 1 than 0 , and their VIF levels are closer to 1 than 10 , demonstrating that almost no multicollinearity issue occurred in our analysis.

All the variables for DA and REM are statistically non-significant at 5\%. This finding differs from those of previous studies. Most of such studies showed that debt dependency level affects earnings management for DA and REM. Jelinek (2007), however, suggested that increased leverage is related to a reduction in earnings management. Thus, the effects of leverage on earnings management may need additional study in the context of the RMC industry. 
Table 7. Regression Results on Effects of Debts Dependency on Earnings Management

\begin{tabular}{|c|c|c|c|c|c|c|}
\hline \multirow{2}{*}{ Input Variables } & \multicolumn{2}{|c|}{ DA } & \multicolumn{2}{|c|}{ REM } & \multirow{2}{*}{ Tolerance } & \multirow{2}{*}{ VIF } \\
\hline & B & $\mathbf{t}$ & B & t & & \\
\hline Constant & -.058 & -.203 & -.043 & -.260 & & \\
\hline SIZE & .004 & .159 & .004 & .261 & .920 & 1.087 \\
\hline LEV & -.003 & -.398 & .003 & .594 & .411 & 2.431 \\
\hline ROA & .198 & 1.153 & -.047 & -.482 & .449 & 2.227 \\
\hline GRW & -.016 & -.350 & -.023 & -.861 & .877 & 1.140 \\
\hline TA & .082 & 1.111 & .017 & .412 & .926 & 1.080 \\
\hline LOSS & .002 & .069 & .012 & -.739 & .558 & 1.791 \\
\hline DEBT & .081 & 1.191 & -.011 & -.279 & .390 & 2.565 \\
\hline Year Dummy & \multicolumn{2}{|c|}{ Included } & \multicolumn{2}{|c|}{ Included } & & \\
\hline$R^{2}\left(\triangle R^{2}\right)$ & \multicolumn{2}{|c|}{$.022(.008)$} & \multicolumn{2}{|c|}{$.029(.00)$} & & \\
\hline $\mathrm{F}$ & \multicolumn{2}{|c|}{.545} & \multicolumn{2}{|c|}{.719} & & \\
\hline
\end{tabular}

\section{CONCLUSION}

This study was aimed at examining the major relationships between key financial indicators, such as cash flows from operations, operating income, and debt dependency level, and earnings management in the RMC industry in Korea. We used 176 firm-year observations as bases in the analyses and verified the moderating effects of operating income on the relationship between operating cash flows and earnings management. We used the model of Kothari et al. (2005) as a proxy for AEM and the model put forward by Cohen et al. (2008) as a proxy for REM.

We developed four hypotheses, for which the test results are as follows. First, cash flows from operations are statistically significant at the $0.1 \%$ level for both AEM and REM. Companies with low cash generation exhibit a stronger tendency toward upward earnings management in AEM and REM. Second, the RMC companies' operating income levels affect AEM and REM at statistically significant levels. Companies with low operating incomes also exhibit a high potential to adopt upward earnings management. Third, operating income exerts different moderating effects on the relationship between operating cash flows and earnings management. That is, no statistical significance was found for AEM, whereas statistical significance at the 5\% level was found for REM. Fourth, the RMC companies' debt dependency levels are statistically non-significant for AEM and REM—a result that deviates from those of previous studies.

This study shows that incentives for implementing upward earnings management in AEM and REM differ depending on financial indicators. Looking into operating income and cash flows from operations enabled us to determine the possibilities that characterize earnings engagement by RMC companies in Korea. When companies have low operating cash flows and operating incomes, they implement both AEM and REM, regardless of their debt dependency levels. Unlike previous studies, the present work determined that debt dependency level is statistically non-significant for both AEM and REM in Korea's RMC industry. In their study on the Korean construction waste disposal industry, Kim and Lee (2015) showed that companies with high debt dependency levels tend to more aggressively pursue AEM. Overall, the companies examined in the current research implement aggressive earnings management, but this decision depends more on operating income and cash generation ability than on debt dependency. As the first study on earnings management in Korea's RMC industry, this research's results can provide insights for those who are interested in accounting information on the aforementioned industry.

Similar to other studies, this research also has certain limitations. We used only 176 firm-year observations because a small number of companies in Korea's RMC industry disclose their financial conditions on the Korean SEC website. Accordingly, this limits the generalizability of our findings. Researchers can expand our work by including more data as the Korean government strengthens its financial disclosure system. For data purity, we excluded companies that engage in businesses other than RMC. The robustness of research in this context can be strengthened by including RMC companies that are multi-business enterprises. Researchers can also extend earnings management study to other industries for comparison and for the identification of characteristics that are unique to the earnings management practices of Korea's RMC industry. 


\section{AUTHOR BIOGRAPHIES}

Geun Bae Jang, Ph.D. Candidate in Business Administration at Seoul School of Integrated Sciences \& Technologies University (aSSIST), Seoul, South Korea. Email: kbjang2@gmail.com (First author). Mailing: 46, Ewhayeodae 2-gil, Seodaemun-gu, Seoul, 03767, South Korea

Weon-Jae Kim, Professor of Accounting, Incheon National University, Incheon, South Korea. Email: kwj5502@inu.ac.kr (Corresponding author). Mailing: (Songdo-dong) 119 Academy-ro, Yeonsu-gu, Incheon, 22012 , South Korea

\section{REFERENCES}

Ashbaugh, H., LaFond, R. and Mayhew, B. (2003). Do Non-Audit Services Compromise Auditor Independence? Further Evidence. The Accounting Review 78 (3): 611-639.

Becker, DeFond, Jiambalvo, C. M. and Subramanyam, K. (1998). The Effect of Audit Quality on Earnings Management. Contemporary Accounting Research 15 (1): 1-24.

Choi, H. S. (2008). Re-examination on the Debt Covenant Hypothesis for Earnings Management. Korean Accounting Review 33 (1): 69-96

Chou, D. W.,Wang, E., Chen, S. S. and Tsai, S. (2009). Earnings management and the long-run underperformance of firms following convertible bond offer. Journal of Business Finance \& Accounting 36 (1) (2): 73-98

Cohen, D., Dey, A. and Lys, T. (2008). Real and accrual based earning management in the pre and post Sarbanes-Oxley periods. The Accounting Review 83 (3): 757-787. and Zarowin, P. (2010). Accrual-based and real earnings management activities around seasoned equity offerings. Journal of Accounting and Economics 50 (1): 2-19

Dechow, P. M., Sloan, R. G. and Sweeney, A. P. (1995). Detecting earnings management. The Accounting Reviews 70 (2): 193-225.

Kothari, S. P. and Watts, R. (1998). The relation between earning and cash flows. Journal of Accounting and Economics 25: 133-168.

DeFond, M. and Jiambalvo, J. (1994). Debt covenant violation and manipulation of accruals. Journal of Accounting and Economics 17 (1-2): 145-176.

DeFond, M. L. and Subramanyam, K. R. (1998). Changes and discretionary accruals. Journal of Accounting \& Economics 25 (1): 35-68.

Fung, S. Y. K. and Goodwin, J. (2013). Short-term debt maturity, monitoring and accrual-based earnings management. Journal of Contemporary Accounting \& Economics 9 (1): 67-82.

Healy, P. M. and Walhen, J. M. (1999). A review of the earning management literature and its implication for standard setting. Accounting Horizon 13 (4): 365-383.

Hue, K. B. (2009). The Study of Earnings Management to Avoid Earnings Losses with Operating Cash Flows and operating incomes. Global Business Administration Review 6 (2): 125-141

Jelinek, K. (2007). The effect of leverage increases on earnings management. Journal of Business \& Economic Studies 13 (2): 24-46.

Jones, J. (1991). Earning management during import relief investigations. Journal of Accounting Research 29 (2): $193-228$.

Jones, S. R. Sharma. (2001). The impact of free cash flow, financial leverage and accounting regulation on earnings management in Australia's "old" and "new" economies. Managerial Finance 27 (12): 18-39.

Kasznik, R. (1999). On the association between voluntary disclosure and earnings management. Journal of Accounting Research 37 (1): 57-821.

Kim, D. B. and Lee, H. I. (2015). The Study of Earnings Management Behavior in the Construction Waste Disposal Industry by Leverage Level and Cash Flows from Operating Activities. Korea International Accounting Review 64: 147-182.

Kim, E. J., Kim, H. B. and Ahn, Y. Y. (2011). The Relations between Financial Characteristics and Earnings Management in Domestic Travel Agencies. Korean Journal of Business Administration 24 (4): 1919-1941.

Kim, J. H., Bae, J. H. and Ko, J. M. (2009). The Effect of Real Earnings Management on Long Term Performance. Korean Accounting Review 34 (4): 31-70.

Kim, J. O. and Bae, G. S. (2008). Small Profits, Small Losses, and Earnings Management: An Analysis Using Unlisted Firms. Korean Accounting Journal 17 (1): 161-193.

Kim, M. T. and Jung, H. G. (2016). A Study on Differential Earnings Management and Earnings Management by Firm Characteristics in the Construction Industry. Korea International Accounting Review 65: 29-48

Kim, S. H. and Sohn, S. K. (2011). Accounting Information Quality in Different Industries. Korean Accounting Review 36(3): 179-215.

Kothari, S. P., Leone A. J. and Wasley C. E. (2005). Performance matched discretionary accrual measures. Journal of Accounting and Economics 39: 163-197. 
Nekhili, M, Amar, I. F. B., Chtioui, T. and Lakhal, T. (2016). Free cash flow and earnings management: The moderating role of governance and ownership. The Journal of Applied Business Research 32 (1): 255-268

Paek, W. S. and Yoo, J. K. (2003). Comparison of earnings quality between construction and other industries. Korean Accounting Journal 13 (1): 147-170

Park, J. I., Lee, S. Y. and Kim, K. H. (2002). Earnings Management of Firms subject to the Tax Minimization and Cash Flows from Operations. Korean Journal of Taxation Research 19 (1): 185-222.

Park, S. H., Kim, Y. S. and Hong, Y. S. (2015). The Patterns of Earnings Management of the Delisted Companies and the Effect of Substantial Investigation System of Delisting on Earnings Management. Korea International Accounting Review 60: 123-158.

Park, S. Y. (2016). The effect of short-term debt on accrual based earnings management and real earnings management. The Journal of Applied Business Research 32 (4): 1287-1300

Park, W. and Park, S. K. (2014). Interaction between Financing and CSR Affecting Earnings Management. Korea International Accounting Review (55): 109-124.

Park, Y. K. (2012). Accrual Based and Real Earnings Management in Korean Firms: Substitutionary or Complementary Relation? Korean Corporation Management Review 19 (6): 43-58.

Ragan S. (1998). Earnings management and the performance of seasoned equity offerings. Journal of Financial Economics 50 (1): 101-122.

Rodriguez P. (2010). Debt, diversification and earnings management. Journal of Accounting and Public Policy 29 (2): 138 159.

Roychowdhury, S. (2006). Earnings management through real activities manipulation. Journal of Accounting and Economics 42 (3): 335-370.

Schipper, K. (1989). Commentary on earning management. Accounting Horizons 3: 91-102.

Sercu, P., Bauwhede, H. and Willekens, M. (2006). Earnings management and debt. Working paper. Katholieke Universiteit: 1-25.

Stickney, C. P., and Weil, R. M. (2007). Financial accounting, an introduction to concepts, methods, and uses. Thompson South-Western. USA.

Sung, Y. W. (2009). Effects of Tightening Financial Regulations on the Trade - off Relationship between Tax Costs and Financial Reporting Costs in the Construction Business. Accounting Information Research 27 (4): 117-146.

Yang, D. J., Ko., D. Y. and Yoon, S. S. (2009). The Effect of Leverage on the Accounting Choices for Loss-Reporting Firms. Management Research 24 (2): 81-106.

Yi, H. D. (2005). Reduction of Debt Equity Ratio and Earnings Management. Management Research 20 (3): $105-132$.

Choi, S. K. and Kim, K. M. (2005). Debt/Asset Ratio and Earnings Management. Korean Accounting Review 30 (3): $113-146$.

Yoon, S. S. and Miller, G. A. (2002). Cash from operations and earnings management in Korea. The International Journal of Accounting 37 (4): 395-412.

Zang, A. Y. (2012). Evidence on the trade off between real activities manipulation and accrual-based earnings management. The Accounting Review 87 (2): 675-703 